\title{
BUDAYA TAWUR DI INDONESIA
}

\author{
Syamsudin \\ Fakultas Humaniora dan Budaya Junusan Bahasa dan Sastra Arab \\ Universitas Islam Negeri (UIN) Malang \\ Jl. Gajayana 50 Malang 65144 Telp. 0341-551354, 558882 \\ Faks. 0341-572533, 0341- 558882
}

\begin{abstract}
"Tawur" is very popular recently. Its popularity is getting more and more in line with its publication in some mass media as newspapers, magazines, televisions, and internet. Many groups of society such as Junior or Senior High School students, University students, lecturers, private or government officials, football supporters and others, have done it. They do it in many places like schools, streets, markets, private or government offices, football stadium, etc. In general, it could be classified into two forms, they are physical and spiritual "Tawur". Physical Tawur could be ended by breaking, burning, torturing or even killing. While spiritual Tawur could be ended by isolation to an individual. Further, it could be ended by an assassination of the individual character. So, both of them have caused many disadvantages either for the Indonesian society or the Indonesian government. Therefore, we must omit Tawur that has become part of our culture. Then, we can change it with a culture that is constructive and benefacial in all aspects of the Indonesian life.
\end{abstract}

Keywords: physical "tawur", spiritual "tawur", character assassination

\section{Pendahuluan}

Beberapa bulan terakhir, negara kita diguncang oleh realitas tawur yang terjadi di berbagai wilayah. Tawur sendiri adalah sebuah bentuk konflik, bisa bersifat fisik ataupun batin. Tawur juga melibatkan banyak kalangan, mulai dari anak-anak, remaja, sampai orang tua. Tempatnya juga bervariasi, mulai dari sekolah, pasar, jalan-jalan raya, perkampungan warga, lapangan sepak bola, kampus, kantor pemerintah/swasta, gedung MPR/ DPR, dan lain-lain. 
Tawur saat ini bahkan begitu popular. Popularitasnya semakin berkibar setelah berbagai media mulai dari majalah, surat kabar, radio, televisi, dan internet gencar merilis tawur yang sedang mewabah di Tanah Air kita yang tercinta ini. Lantas ada apa- dengan masyarakat kita? Mengapa mereka menyukai tawur? Bagaimana pula tawur bisa menjadi bagian dari 'budaya' bangsa Indonesia?

\section{Tawur yang Mewabah}

Ibarat sebuah penyakit, tawur ternyata juga sudah mewabah ditengah masyarakat Indonesia. Bahkan tawur yang bisa bersifat fisik dan juga batin itupun rupanya digemari:banyak kalangan. Hal ini terlihat dari pelaku tawur itu sendiri yang sangat beragam. Mulai dari para oknum pelajar SD, SMP, SMU, mahasiswa, dosen, pejabat pemerintah/swasta, bahkan kalangan DPR/ MPR - pun juga suka tawur. Tawur seolah-olah telah mejadi obat yang mujarab untuk menyelesaikan setiap masalah yang ada. Sehingga setiap permasalahan selalu diakhiri dengan tawur.

Saat ini, tawur yang sering kita jumpai adalah tawur yang dilakukan antar pelajar SMU. Tawur jenis ini bersifat fisik. Dan tawur ini biasanya diakhiri dengan jatuhnya korban, baik luka-luka sampai pada hilangnya nyawa pelaku tawur. Contohnya adalah tawur yang terjadi antara pelajar SMAN I dan SMAN II di depan SMAN I Makasar Jl. Gunung Bawa Kareang telah memakan korban. Dua siswa SMAN II yang terlibat aksi saling kejar meninggal setelah motor yang dikendarai mengalami kecelakaan. (Jawa Pos, 29/11/06). Sementara itu, beberapa saat yang lalu di Ibu Kota terjadi tawur antar pelajar SMU. Tawur tersebutberakhir dengan tewasnya seorang pelajar akibat kecelakaan. (Metro TV, ../12/06)

Tawur yang dilakukan oleh kalangan remaja umumnya tidak mengenal tempat. Tawur tidak hanya dilakukan disekitar sekolah ataupun jalan raya. Tawur juga dapat terjadi disebuah konser musik. Hal ini menimpa kelompok musik Slank. Konser yang bertujuan mulia dengan tema konser amal, harus ternoda dengan tawur yang dilakukan oleh penontonnya. "Konser kelompok musik Slank di stadion Maron Kecamatan Genteng, Banyuwangi diwarnai tawuran. Akibatnya, kepala seorang Slanker (Pecinta Slank) bocor. Beruntung insiden tersebut tidak berlangsung lama, karena 
petugas keamanan segera menguasai keadaan. Kaka, vocalis Slank juga berusaha mendinginkan emosi para Slankers. ...Konser yang dimulai pukul 19.45 itu awalnya berjalan tertib. Tetapi keadaan berubah saat Kaka mulai menyanyikan lagu ketiga yang berjudul Malam Minggu. Lagu tersebut terpaksa harus dinyanyikan separo karena para Slankers dibagian selatan tiba-tiba terlibat tawuran. Salah seorang penonton terpaksa diamankan petugas karena kepalanya bocor. (Jawa Pos, 25/1 1/06)

Selain tawur antar pelajar SMU, Tawur antar supporter sepak bola juga menjadi trend. Sebagai contohnya adalah tawur yangdilakukan antara supporter AREMA Malang melawan PERSEBAYA Surabaya. Saat itu, PERSEBAYA selaku tuan rumah yang menjamu AREMA mengalami kekalahan. Akibatnya para pendukung PERSEBAYA yang biasa disebut Bonek ini tidak terima. Merekapun kemudian melampiaskan kekecewaan mereka dengan cara mengamuk dan melakukan banyak perusakan. Berbagai fasilitas yang ada di stadion menjadi sasaran amuk. Lebih dari itu mereka juga membakar motor dan juga mobil yang melintas di depan mereka. Mereka juga melakukan pemukulan terhadap pemakai jalan yang belum tentu supporter AREMA. (Jawa Pos, 4/09/06)

Tawur antar pelajar SMA dan juga antar supporter sepakbola hampir menjadi makanan kita sehari-hari. Tawur ini tidak asing bagi telinga dan juga penglihatan kita. Tawur lainnya yang sekarang dapat kita jumpai adalah tawur yang dilakukan antar warga kampung. Hal ini pula yang terjadi saat rembuk desa disuatu wilayah di Malangdiwarnai dengan tawur. Musyawarah warga guna menyikapi pembangunan kantor kelurahan Oro Oro Dowo yang bakal dibangun di Taman Kunir kemarin malam berakhir ricuh. Beberapa orang yang dikenal dari kelompok yang pro pembangunan mulai emosi dan bersitegang dengan kelompok yang kontra. ...Dalam kericuhan sekitar pukul 21.30 WIB tersebut Subaryo, Ketua Forum Independen Masyarakat Malang (FIMN) mendapat perlakuan fisik. Pria vocal tersebut didorong dan diancam. Bahkan, Subaryo mengaku sempat ada yang memukulnya. (Jawa Pos, 15/11/06)

Ternyata tawur tidak hanya terjadi antar warga kampung. Tawur juga dapat terjadi antara warga dan aparat. Misalnya, karena merasa dilecehkan puluhan warga desa Bayem Taman, Kecamatan Kartoharjo Magetan 
kemarin nggeluruk kantor camat Kartoharjo. Mereka memprotes kebijakan Camat Heru Sulistyo yang dinilai arogan dan sewenang-wenang dalam menetapkan pejabat sementara kepala desa mereka. (Jawa Pos, 22/11/06)

Bahkan yang terbaru adalah tawur yang dilakukan oleh para jamaah haji kepada seorang menteri agama dalam kabinet SBY. Menteri yang sedianya mengadakan kunjungan iru menjadi korban amuk para jemaah yang tidak terima dengan pelayanan yang mereka dapat saat musim haji tahun ini. Sebagaimana ditulis media; MINA-Emosi jamaah haji RI yang kelaparan tampaknya sudah memuncak. Mereka menumpahkan segala kesalahan kepada Menteri Agama (Menag) Maftuh Basyuni dan jajaran pejabat PPIH (Panitia Penyelenggara Ibadah Haji) di Arab Saudi...Saat itu rombongan Maftuh baru tiba di maktab 39. Nah, sampai di pintu gerbang maktab, Maftuh dihampiri beberapa jamaah. Mereka terlihat adu mulut dengan rombongan pejabat Depag tersebut. Tanpa diduga, satu dua jamaah tiba-tiba melepaskan pukulan kearah Maftuh. Situasi menjadi tak terkendali... Begitu Maftuh menjadi sasaran massa, beberapa petugas spontan mengamankannya." (Jawa Pos, 2/01/07)

Dari sekian tawur fisik yang ada, tawur yang paling berbahaya bagi keutuhan NKRI adalah tawur antar warga negara yang mengandung unsur SARA. Tawur fisik jenis ini biasanya melibatkan tidak hanya puluhan ataupun ratusan warga. Lebih dari itu tawur berbau SARA ini dapat melibatkan berbagai suku di Indonesia yang jumlahnya ribuan.

Masih lekat dalamingatan kita beberapa tahun silam saat terjadi tawur antara suku Madura vs Dayak yang terjadi di Sampit, Kalimantan. Dikabarkan tawur antar suku tersebut telah merenggut ratusan nyawa, mulai dari anak-anak sampai orang tua, melayang. Selain korban nyawa, harta benda yang tak terhitung jumlahnya juga ikut melayang.

Terakhir adalah kasus Tibo cs. Eksekusi pelaku pembunuhan berbau SARA itu ternyata menimbulkan gelombang protes yang diakhiri dengan pembakaran dan perusakan. "Ribuan massa yang menolak eksekusi Tibo cs membakar dan merusak kantor Kejaksaan Negeri Atambua dan Lapas Atambua. Akibatnya 205 tahanan dan narapidana kabur... Tibo cs terlibat dalam pembantaian massal di Poso pada tahun 2000. Ketiganya adalah komandan lapangan dalam aksi perusakan dan pembunuhan berbau SARA 
(Suku, Agama, Ras, dan Antar Golongan) dengan korban lebih dari 200 orang. ...Dalam sidang Pengadilan Negeri Palu ketiganya divonis mati. Setelah berbagai proses hukum untuk meringankan vonis tersebut kandas, eksekusipun dilakukan. Eksekusi kemarin telah mengalami beberapa penundaan menyusul protes dan keberatan beberapa pihak di luar negeri. (Jawa Pos, 21/09/06)

Selain semua tawur yang bersifat fisik di atas, ada jenis tawur lain yang tidak kalah dasyatnya. Tawur ini adalah tawur batin. Sama halnya seperti tawur fisik, tawur batin juga dapat dilakukan oleh semua unsur masyarakat, mulai dari pelajar, mahasiswa, dosen, warga kampung/ masyarakat, pejabat pemerintah/swasta, bahkan anggota MPR dan DPR.

Tawur batin antar mahasiswa dan pelajar dapat terjadi dimana saja. Ini terjadi kerena pelajar dan mahasiswa tersebut memiliki kelompok organisasi yang berbeda dengan tujuan organisasi yang berbeda pula. Dan untuk memperjuangkan tujuan organisasi yang mereka ikuti tidak jarang mereka berselisih paham dengan pelajar ataupun mahasiswa dari kelompok/ organisasi lainnya. Selisih pendapat ini berujung kepada sebuah tawur batin.

Dampak dari tawur batin tersebut adalah berkurangnya rasa persahabatan ataupun persaudaraan antar pelajar dan mahasiswa. Hal ini terjadi karena adanya sifat eksklusifisme dari pelajar ataupun mahasiswa yang bersangkutan. Sifat tersebut seringkali membuat individu merasa lebih dibandingkan dengan pelajar ataupun mahasiswa yang tidak seorganisasi. Lebih jauh sifat eksklusifism ini akan menjadi embrio yang sangat potensial pada perpecahan untuk selanjutnya mudah memicu tawur fisik yang ada dimasyarakat.

Selain dilakukan oleh pelajar dan mahasiswa, tawur batin juga dapat terjadi antara mahasiswa, dosen dan juga para pejabat kampus. Hal ini sering terjadi dibanyak kampus di Indonesia. Tawur batin yang terjadi antara mahasiswa, dosen dan para pejabat kampus dapat disebabkan oleh adanya perbedaan sudut pandang dalam mencermati sebuah permasalahan.

Selain itu, tawur batin yang mereka lakukan juga dapat disebabkan oleh kehidupan dinamika kampus yangbergerak begitu cepat dan menuntut kesiapan SDM. Yang pada kenyataannya banyak dari individu di dalamnya belum siap. Sehingga proses belajar mengajar ataupun administrasi yang 
ada tidak dapat berjalan dengan baik. Hal inilah yang pada gilirannya akan memunculkan berbagai permasalahan di dalam kampus.

Segala permasalahan tersebut selanjutnya memunculkan tawur batin antara mahasiswa, dosen serta para pejabat kampus. Akibatnya, pengembangan iklim akademik dan juga pembangunan fisik dari kampus yang bersangkutan menjadi tcrhambat. Pada gilirannya yang dirugikan adalah pelaku tawur itu sendiri selain masyarakat sekitar kampus.

Selain karena perbedaan dalam mencermati suatu permasalahan, tawur batin yang ada di lingkungan kampus juga dapat disebabkan oleh adanya keragaman tujuan dari individu yang ada di dalamnya. Pada kenyataannya, guna mewujudkan tujuan atau cita-citanya tersebut, seringkali ia berbenturan dengan individu lainnya. Lebih jauh hal ini akan memunculkan tawur yang bisa bersifat implisit dan eksplisit. Senada dengan pendapat tersebut Jung menyatakan bahwa tingkah laku manusia, termasuk kepribadiannya, dikondisikan tidak hanya oleh individu dan sejarah

tetapi juga oleh tujuan dan aspirasinya. (Lynn: 2

Tawur batin lainnya dapat terjadi antar warga kampung. Tawur batin ini dapat disebabkan oleh adanya segala permasalahan yang ada di kampung tersebut. Dampaknya adalah berkurangnya rasa kerukunan di kampung itu sendiri. Dan pada akhirnya, hal ini akan menghambat laju pembangunan kampung yang bersangkutan.

Tawur batin juga dapat terjadi antar pejabat pemerintah. Salah satu contoh paling gress adalah tawur batin yang melibatkan dua pejabat dalam kabinet SBY yaitu Menteri Sekretaris Negara, Yusril Ihza Mahendra dengan Ketua Komisi pemberantasan Korupsi, Taufiqurrahman Ruki. "Dikabarkan menghilang tiga hari, Menteri Sekretaris Negara, Yusril Ihza Mahendra, muncul di depan wartawan kemarin. Dalam kesempatan itu, dia kembali menegaskan sikapnya seputar kasusnya dengan ketua KPK, Taufiqurrachman Ruki. Bahkan ketika kasus itu dikaitkan dengan isu reshuffle, Yusril mengaku tidak takut...Yusril diperiksa oleh KPK 8 jam. Dia diperiksa sebagai saksi dalam kasus pengadaan barang tanpa tender, yakni pengadaan alat sidik jari otomatis - Automatic Fingerprint Identification System (AFIS) pada 2004. Saat itu, Yusril menjabat menteri Hukum dan HAM. (Jawa Pos, 21/02/07) 
Selain itu, tawur batin juga dapat terjadi antara Lembaga Eksekutif, Legislatif dan Yudikatif. Dampak dari tawur batin yang mereka lakukan dapat berupa keluarnya berbagai kebijakan yang tidak populis. Pada akhirnya, kebijakan tersebut akan merugikan rakyat secara keseluruhan.

Dari sekian tawur batin yang ada, yang paling berbahaya adalah tawur batin yang berbau SARA (Suku, Agama, Ras, dan Antar Golongan). Tawur batin yang satu ini sangat membahayakan keutuhan NKRI. Bahkan, tawur batin jenis ini mudah sekali dipicu oleh isu-isu yang tidak benar yang dilontarkan oleh orang-orang yang tidak bertanggung jawab. Pada akhirnya tawur batin berbau SARA ini sangat rentan memunculkan kekacauan/ kerusuhan yang bersifat fisik dengan skala nasional.

\section{Tawur Yang Membudaya}

Berdasarkan uraian di atas, terlihat jelas bahwa masyarakat kita demam tawur. Baik fisik maupun batin. Data di atas hanyalah sekelumit dari tawur yang telah terjadi di Indonesia. Hal ini terlihat dari tawur yang telah dan sedang terjadi di berbagai wilayah di tanah air dan dilakukan oleh berbagai kalangan.

Telah dan sedang berlangsungnya tawur, fisik dan batin, yang dilakukan oleh berbagai kalangan ditanah air kita ini, sadar atau tidak sadar kita telah menjadikan tawur sebagai bagian dari budaya kita. Tawur telah membudaya. Tawur bahkan telah menyatu dalam denyut nadi masyarakat Indonesia.

Pertanyaannya, bagaimana tawur bisa menjadi bagian dari budaya kita? Bagaimana mungkin Indonesia yang di dunia internasional dikenal sebagai negara dengan semboyan Bhinneka Tunnggal lka, dengan kehidupan masyarakatnya yang terkenal rukun dan ramah bisa pecah dan bahkan memiliki salah satu dari budaya barbar yaitu tawur?

Sebuah teori budaya Honigman dalam bukunya The World Man menyatakan adanya 3 bentuk kebudayaan. Yang pertama adalah kebudayaan sebagai suatu kompleks ide; Kedua kebudayaan sebagai suatu kompleks aktivitas; Ketiga kebudayaan sebagai hasil karya manusia. (Koentjaraningrat, 2000). 
Pendapat Honigman di atas bisa disimpulkan bahwa tawur telah menjadi budaya baru rakyat Indonesia. Dan budaya baru ini begitu cepat merasuk, menyatu dalam darah masyarakat Indonesia. Lebih dari itu alam pikir masyarakat kita juga telah tercemar dengan budaya tawur yang sekarang bahkan menjadi trend bagi masyarakat kita. Sehingga hal-hal kecil yang bersifat provokatif akan dengan mudah memicu timbulnya tawur.

Tawur yang bersifat fisik biasanya diakhiri dengan jatuhnya korban jiwa dan harta. Korban harta terjadi akibat dari perilaku destruktif yang dilakukan oleh pelaku tawur. Biasanya mereka akan melakukan pembakaran dan juga perusakan terhadap berbagai sarana yang ada sebagai sasaran amuk. Perusakan dan pembakaran tersebut adalah sebuah ekspresi dari alam pikir yang telah terkontaminasi dengan budaya tawur dalam waktu yang cukup lama. Tawur bahkan mengontrol serta menguasai jiwa individu. Kemudian jiwa ataupun pikiran yang telah tercemar dengan tawur cukup lama tersebut akan sangat mudah diprovokasi untuk melakukan tawur, dan dari sinilah budaya tawur itu terbetuk.

Biasanya individu yang jiwa ataupun pikirannya telah terkontaminasi dengan budaya tawur, mudah terpancing untuk melakukan tindakan yang bersifat destruktif. Bahkan hanya karena masalah sepele, ia rela melakukan perusakan, pembakaran, dan kalau perlu pembunuhan.

Seperti yang kita ketahui bersama bahwa tawur, fisik utamanya, telah banyak menimbulkan kerugian harta dan jiwa. Tak terkecuali bagi masyarkat Indonesia yang sekarang ini sedang demam tawur. Hasil kegiatan ataupun tindakan tawur sangat kasat mata. Yaitu berujung pada suatu pembakaran, perusakan dan juga pembunuhan. Dampak tawur fisik benarbenar mengerikan! (Lihat saja kasus pembantaian yang dilakukan setiap pelaku tawur yang berbau SARA di berbagai wilayah di tanah air kita ini!)

Walaupun dampak dari tawur fisik sangat mengerikan, namun dampak dari tawur batin juga tidak kalah dasyatnya! Oleh karena itu, meskipun tawur batin tidak diekspresikan dalam bentuk perusakan dan pembakaran, tetapi dampak dari tawur batin dapat diakhiri dengan isolasi, antipati, yang pada akhimya berujung pada pembunuhan karakter.

Lantas bisakah kita menghilangkan budaya tawur, fisik dan batin, yang telah mengakar dalam jiwa masyarakat Indonesia? Apa yang harus 
kita lakukan untuk mengembalikan kehidupan masyarakat kita kepada suatu kehidupan yang berbudaya, rukun dan ramah?

Banyak orang, terutama para ahli ilmu sosial mengartikan konsep kebudayaan dalam arti yang amat luas yaitu seluruh total dari pikiran, karya, dan hasil karya manusia yang tidak berakar dari nalurinya, dan yang karena itu hanya bisa dicetuskan oleh manusia sesudah suatu proses belajar. (Koentjraningrat: 2000)

Berdasarkan hal tersebut, kebudayaan bisa terbentuk setelah melalui suatu proses pembelajaran. Proses pembelajaran dalam pembentukan sebuah budaya bisa berlangsung secara sengaja/langsung dan tidak langsung/tidak sengaja. Kebudayaan yang dibentuk secara sengaja biasanya dilakukan dalam bentuk pembelajaran. Sebagai contohnya adalah proses kegiatan belajar mengajar di sekolah. Kebudayaan tersebut dibentuk dengan melibatkan guru/tutor dan juga murid. Dan dengan setting tempat yang telah ditentukan.

Namun budaya juga dapat dibentuk melalui sebuah pembelajaran tidak sengaja. Budaya jenis ini dipelajari secara insidental dengan durasi yang berulang-ulang. Sedangkan setting tempatnya bisa beragam. Bisa di rumah, sekolah, kampus, jalan raya, pasar, kantor (pemerintah/swasta), lapangan sepak bola, konser musik, gedung MPR DPR, dan sebagainya. Dan tawur adalah salah satu bentuk budaya yang telah kita pelajari secara langsung/tidak langsung.

Dalam sebuah teori belajar sosial, Lynn menyatakan bahwa tingkah laku manusia (yang merupakan kepribadian kita) adalah interaksi timbal balik antara determinan kognitif, tingkah laku dan lingkungan. Kita belajar bagaimana menjadi diri kita tidak hanya melalui pengkondisian, seperti anjingnya Pavlov yang mengeluarkan air liur pada saat bel berbunyi, tetapi juga melalui observasi tingkah laku orang lain. (Lynn, 2001: 279)

Sementara itu, lebih jauh Perls menekankan bahwa kita semua memiliki polaritas dalam diri yang haruṣ diterima dan atau direkonsiliasikan. Orang berfungsi sebagai unit total dan totalitas diri merupakan rangkaian proses yang dipelajari melalui interaksi individu yang bersifat tetap dengan dirinya sendiri dan lingkungannya. ( Lynn, 2001: 278) 
Memang tawur, baik fisik ataupun mental, telah kita pelajari secara sengaja atau tidak sengaja semenjak kita masih kanak-kanak. Hal ini tentu saja didukung oleh pemberitaan berbagai media utamanya televisi yang telah menyiarkan berbagai acara yang berbau kekerasan.

Kita juga sering menjumpai program-prgram yang mengandung unsur kekerasan yang telah disiarkan oleh berbagai stasiun TV yang ada di Negeri kita ini. Adapun bentuk programnya bisa berupa sinetron dan juga film yang menampilkan adanya perdebatan dan perkelahian, selain juga berbagai hiburan ataupun breaking news tentang peristiwa-peristiwa aktual yang menontonkan berbagai kekacauan dan pembunuhan yang terjadi dimasyarakat di berbagai belahan dunia. Contohnya adalah acara Smack Down, tawur antar pelajar SMA, tawur antar mahasiswa, tawur antar supporter sepakbola, tawur antar penggemar musik, tawur antar warga, tawur antar suku, tawur antar warga dan aparat, sampai pada tawur antar pejabat pemerintah/anggota DPR dan MPR. Sekali lagi tawur yang dilakukan bisa bersifat fisik dan juga batin.

Jenis tontonan ataupun hiburan semacam itu akan merasuk dalam alam pikir kita. Dan secara tidak kita sadari, kita secara cerdas telah menjadi pembelajar ilmu tawur yang berhasil dengan teramat sangat sukses. Sehingga saat tawur telah menguasai alam pikir kita, hanya karena dipicu oleh permasalahan sepele, kita akan menjadi sangat mudah melakukan tawur.

Bahkan pada saat era Presiden Suharto yang terkenal dengan era Orde Baru, ada pepatah Jawa yang begitu popular, yang langsung ataupun tidak langsung telah menyuburkan adanya budaya tawur. Pepatah ini dipuja oleh banyak kalangan di Indonesia. Adapun bunyi dari pepatah tersebut adalah "Jamane Edan Ora Edan Ora Komanan".

Dari pepatah Jawa tersebut, jika dikaitkan dengan era Orde Baru, kita akan langsung tertuju pada budaya $\mathrm{KKN}$ yang begitu tumbuh subur di Negara kita ini. Yang perlu diingat adalah $\mathrm{KKN}$ juga bukanlah hal yang mudah. Dan dengan ber-KKN, seseorang dapat melakukan hal apapun untuk mencapai tujuannya. Salah satunya adalah tawur, fisik dan juga batin. Parahnya lagi, pada masa itu orang yang tidak pandaiber-KKN-ria, ataupun 
tidak mampu untuk melakukan tawur fisik dan juga batin, justru dianggap sebagai seorang yang telah gagal dalam hidup.

Tentu saja kita tidak perlu memelihara budaya $\mathrm{KKN}$ yang justru menjadi pemicu munculnya budaya tawur yang tumbuh subur di masyarakat kita. Bahkan kita harus merubah budaya tawur yang terlanjur menjadi bagain budaya masyarkat kita kepada sebuah kebudayaan yang lebih konstruktif dalam segala aspek kehidupan.

Walaupun harus kita akui bahwa untuk merubah sesuatu yang membudaya bukanlah hal yang mudah, diperlukan waktu yang tidak sebentar. Sebab sesuatu yang telah menjadi budaya, sesuai dengan penjelasan sebelumnya, biasanya telah hidup dalam darah kita. Bahkan menyatu dengan denyut nadi kita. Seperti halnya budaya tawur, budaya ini juga telah menjiwa disetiap masyarakat Indonesia. Selanjutnya budaya itu mengontrol alam pikir kita. Sehingga perilaku ataupun tindak-tanduk kita selalu saja mencerminkan budaya yang telah mengusai hidup kita tersebut. Hal ini terjadi dalam tempo yang lama. Oleh karena itulah budaya tersebut sulit dirubah.

Namun bukan berarti budaya tawur tersebut tidak dapat dirubah. Dalam sebuah teori sosiologi disebutkan bahwa perubahan dalam suatu masyarakat adalah sebuah keniscayaan. Perubahan itu meliputi berbagai aspek kehidupan ataupun kebudayaan yang ada dimasyarakat. Perubahan itupun terjadi seiring dengan perubahan waktu ataupun zaman. Dan perubahan terhadap sebuah kebudayaan yang ada dapat kita lakukan secara sadar dan terencana. Hal ini senada dengan pendapat Bohannan yang menyatakan bahwa perubahan terjadi karena usaha-usaha masyarakat untuk menyesuaikan diri dengan keperluan-keperluan, keadaan-keadaan, dan kondisi-kondisi baru, yang timbul sejalan dengan pertumbuhan masyarakat. (Soekanto, 2006: 269)

\section{Kesimpulan}

Untuk itu guna mengendalikan konflik yang telah mewabah dimasyarakat kita akibat dari maraknya budaya tawur, ada tiga langkah yang harus kita lakukan: 
1. Masing-masing kelompok yang terlibat dalam konflik harus menyadari akan adanya situasi konflik diantara mereka, oleh kerena itu mereka harus menyadari perlunya dilaksanakan prinsip-prinsip keadilan secara jujur bagi semua pihak.

2. Pengendalian konflik hanya mungkin dilakukan apabila berbagai kekuatan sosial yang saling bertentangan itu terorganisir dengan jelas. Bila tidak terorganisir, maka pengendalian konflik akan sulit dilakukan. Sebaliknya konflik yang terjadi antar golongan atau kelompok yang terorganisir akan mudah melembaga sehingga akan mudah dikendalikan pula.

3. Setiap kelompok yang terlibat konflik harus mematuhi aturan main tertentu guna menjamin kelangsungan hidup kelompok itu sendiri. Sehingga ketidak adilan dapat dihindarkan, sehingga tiap kelompok dapat meramalkan tindakan yang akan diambil oleh kelompok lain, serta menghindarkan munculnya pihak ketiga yang akan merugikan kepentingan mereka sendiri. (Sudikin, 2003: 117)

Selain itu, ada delapan kesadaran utama yang harus menjadi main stream dari alam pikir masyarakat Indonesia yang bisa kita gunakan untuk merubah budaya tawur yang cenderung destruktif, antara lain:

1. Adanya kesadaran bahwa tawur bukanlah langkah yang benar untuk menyelesaikan setiap permasalahan yang ada.

2. Adanya kesadaran untuk tidak mementingkan diri sendiri dalam menyelesaikan setiap permasalahan yang ada.

3. Adanya kesadaran bahwa tawur hanya merugikan secara materiil dan spiritual (korban harta dan nyawa).

4. Adanya kesadaran akan keragaman suku, ras, agama dan golongan dengan sifat masing masing.

5. Adanya kesadaran untuk dapat menghargai setiap perbedaan yang ada.

6. Adanya kesadaran untuk terus menumbuhkan semangat membangun, toleransi, monghormati, dan gotong royong. 
7. Adanya kesadaran untuk menyelesaikan setiap permasalahan dengan musyawarah.

8. Adanya kesadaran untuk selalu menjunjung tinggi hukum dalam setiap penyelesaian masalah.

Beberapa langkah di atas bisa menjadi alternatif untuk mengikis atau bahkan menghilangkan budaya tawur yang telah menjadi bagian budaya masyarakat kita. Yang jelas untuk merubah sesuatu yang telah menjadi budaya (budaya tawur) diperlukan perencanaan, kerja keras dan kedisiplinan yang harus dilaksanakan secara terus menerus. Hal ini tentu saja menjadi semakin efektif manakala dimulai dari diri kita masing-masing! 


\section{DAFTAR PUSTAKA}

Koentjaraningrat. 2000. Kebudayaan, Mentalitas dan Pembangunan. Jakarta: PT Gramedia Pustaka Utama.

Lynn, Wilcox. 2001. Personality Psychotherapy. Yogyakarta: IRCiSoD. Sudikin, dkk. 2003. Pengantar llmu Budaya. Surabaya: Insan Cendikia. Soekanto, Soerjono. 2006. Sosiologi. Jakarta: PT Raja Grafindo Persada. Jawa Pos, Edisi 15 November 2006 Jawa Pos, Edisi 2 Januari 2007 Jawa Pos, Edisi 21 September 2006 Jawa Pos, Edisi 22 November 2006 Jawa Pos, Edisi 29 November 2006 Jawa Pos, Edisi 29 November 2006 Jawa Pos, Edisi 29 November 2006 Jawa Pos, Edisi 4 September 2006 Jawa Pos, Edisi 21 Februari 2007 Metro TV, Desember 2006 